\title{
GEJALA SOSIAL PADA TIGA CERPEN KALIMANTAN TIMUR TAHUN 1980-AN
}

\section{SOCIAL PHENOMENA OF THREE EAST KALIMANTAN SHORT STORIES IN THE 1980s}

\author{
Diyan Kurniawati \\ Kantor Bahasa Provinsi Kalimantan Timur \\ Jalan Batu Cermin 25, Sempaja Utara, Samarinda \\ Pos-el: kurniadiyan2018@gmail.com
}

*)Naskah diterima: 8 Oktober 2021; direvisi: 15 Oktober 2021; disetujui: 15 November 2021

\begin{abstract}
Abstrak
Penelitian ini bertujuan untuk mengetahui gejala sosial yang terdapat dalam tiga cerpen Kalimantan Timur tahun 1980-an. Ketiga cepen tersebut berjudul "Kembali ke Desa", Surat dari Kekasih", dan "Keping Hati Menguak Badai". Dengan teori sosiologi sastra, penelitian ini menganalisis berbagai gejala sosial yang terjadi dalam relasi tokoh dengan lingkungannya. Analisis menunjukkan bahwa gejala sosial yang terjadi pada ketiga cerpen tersebut berupa tokoh yang menunjukkan pertahanan eksistensinya dengan bermigrasi ke luar daerahnya. Di daerah baru tersebut, tokoh mengalami konflik-konflik selama melakukan pertahanan eksistensi. Konflik-konflik yang terjadi menimbulkan tokoh mengambil keputusan untuk kembali ke daerahnya. Selain konflik-konflik, terdapat pula nilai-nilai sosial yang ditampilkan dalam relasi antarindividu. Nilai-nilai tersebut yaitu solidaritas dan empati. Analisis juga menunjukkan pula terdapat tujuan tokoh melakukan pertahanan eksistensi ke luar daerahnya bukan hanya untuk meningkatkan status ekokonomi dirinya, melainkan untuk kembali dan membangun daerahnya yang belum mengalami kemajuan. Tiga cerpen Kalimantan Timur tahun 1980-an menunjukkan gejala sosial manusia melalui pergulatan pertahanan eksitensi di luar daerahnya.
\end{abstract}

Kata kunci: fenomena sosial, eksistensi, migrasi

\begin{abstract}
This study aims to determine the social phenomena in three East Kalimantan short stories in the 1980s. Those are "Kembali ke Desa", "Surat dari Kekasih", and "Keping Hati Menguak Badai". Using the theory of literature sociology, this research analyzes various social phenomena in characters' relationship with their environment. The analysis shows that the social phenomena in those short stories are characters who defend their existence by migrating from his or her place. In their new environment, the characters experience conflicts while fighting for their existence. Those conflicts make them return to their old place. In addition, there are also social values portrayed in relationships between individuals, solidarity and empathy. The analysis also reveals that there is a purpose in defending their existence away from their home, not only to improve their economic status, but also to return and make their environment a better place. Those three short stories show social phenomena through the struggle of defending existence away from their environment.
\end{abstract}

Keywords: social phenomena, existence, migration 


\section{PENDAHULUAN}

Karya sastra merupakan gambaran kehidupan suatu masayarakat. Sastra menunjukkan fenomena sosial budaya masyarakat. Wellek dan Warren (1993:109) menyebutkan bahwa sastra menampilkan kehidupan. Kehidupan tersebut sebagian besar terdiri atas kenyataan sosial, meskipun karya sastra juga meniru alam dan dunia subjektif manusia. Kehidupan manusia yang dinamis dan semakin kompleks dari waktu menjadikan sastra sebagai fenomena kehidupan mengalami hal yang sama. Dalam Teeuw (2003:264) disebutkan bahwa konsep jenis sastra yang modern bersifat dinamis. Karya sastra berada dalam tegangan konvensi dan kreasi.

Kuntowijoyo (2006:89) menyebutkan bahwa manusia hidup di lingkungan sosialnya. Manusia melakukan interaksi dengan individu lain di sekitarnya. Lingkungan sosial tersebut ialah organisasi sosial, stratifikasi sosial, gaya hidup, dan sebagainya. Kontak dan komunikasi menjadi penting dalam manusia beriteraksi dengan lingkungannya. Menurut Koentjaraningrat (2015:131), dalam proses sosial antara individu dan masyarakat terdapat adanya kontak dan komunikasi. Adanya kontak belum berarti terjadi komunikasi. Tidak adanya komunikasi yang baik tersebut dapat menimbulkan ketegangan atau konflik dalam masyarakat.

Relasi manusia dalam masyarakat tersebut menampilkan berbagai kondisi gejala sosial. Soekanto (2019:311) menyebutkan bahwa gejala sosial yang wajar, seperti norma-norma, kelompok sosial, lembaga kemasyarakatan, proses sosial, perubahan sosial, dan kebudayaan serta perwujudannya. Tidak semua gejala tersebut berlangsung secara normal seperti yang dikehendaki masyarakatnya. Dalam proses sosial tersebut dapat terjadi kontraversi. Soekanto (2019:87--93) menyebutkan bahwa kontraversi merupakan suatu bentuk proses so- sial yang terjadi, seperti pertentangan dan pertikaian. Pertentangan tersebut dapat berupa pertentangan antarpribadi ataupun pertentangan antarkelompok.

Pengarang cerpen Kalimantan Timur 1980-an banyak menampilkan berbagai gejala sosial. Relasi manusia di lingkungannya tersebut merupakan persoalan yang menarik untuk dianalisis lebih lanjut. Oleh karena itu, masalah dalam penelitian ini adalah bagaimana gejala sosial yang terdapat dalam tiga cerpen Kalimantan Timur tahun 1980-an?

\section{LANDASAN TEORI}

Penelitian ini menggunakan teori sosiologi sastra. Wellek dan Warren (1993:110) mengungkapkan bahwa pendekatan sosiologi sastra tidak hanya mempelajari kaitan sastra dengan masyarakat, tetapi juga memberi batasan bagaimana seharusnya hubungan itu dalam masyarakat di zaman sekarang dan masa datang. Damono (2002:1) menyebutkan bahwa sastra tidak dapat dipisahkan dari kehidupan masyarakat. Di dalam sastra terdapat hubungan antara sastrawan, masyarakat, dan sastra.

Sementara itu, kehidupan adalah suatu kenyataan sosial. Oleh karena itu, antara sastrawan, sastra, dan masyarakat terdapat hubungan yang tidak dapat dipisahkan. Selanjutnya, Escarpit (2005:3) menjelaskan bahwa semua fakta sastra menyiratkan adanya penulis, buku, dan pembaca atau secara umum dikatakan sebagai pencipta, karya, dan publik. Prijanto, dkk (2007:7) menjelaskan pula bahwa telaah sosiologis merupakan hal yang tepat untuk mengungkapkan nilai-nilai kemasyarakatan yang tersirat dalam sebuah karya sastra. Endraswara (2002:77) menyebutkan pula bahwa asumsi dasar penelitian sosiologi sastra ialah kelahiran sastra tidak dalam kekosongan sosial. Kehidupan sosial menjadi pemicu lahirnya karya sastra. 
Teori sosiologi sastra dalam penelitian ini akan diterapkan melalui analisis posisi manusia dalam lingkungan sosialnya. Relasi dan konflik antaridividu juga akan dianalisis untuk mengetahui gejala sosial yang terjadi.

\section{METODE PENELITIAN}

Penelitian ini menggunakan metode kualitatif. Data penelitian ini dianalisis secara deskriptif. Bogdan dan Taylor (Moleong, 1993:3) menjelaskan bahwa metode kualitatif adalah penelitian yang datanya berbentuk deskriptif berupa kata-kata tertulis atau lisan dari orang-orang yang perilakunya dapat diamati. Metode ini diarahkan pada latar dan individu secara utuh. Penelitian tidak boleh mengisolasi individu atau organisasi ke dalam variabel atau hipotesis, tetapi perlu dilihat sebagai bagian dari suatu keutuhan.

Langkah-langkah yang dilakukan untuk mengetahui gejala sosial dalam tiga cerpen Kalimantan Timur tahun 1980-an adalah sebagai berikut.

1. Menentukan sumber data penelitian, yaitu tiga cerpen Kalimantan Timur yang berjudul "Kembali ke Desa" karya Mazhar Hanafie (25 Juli 1988), “Keping Hati Menguak Badai" karya Ni Nipah (1 November 1988), dan "Surat dari Kekasih" karya Said Ags.S (5 Januari 1989).

2. Mengidentifikasi cerpen-cerpen tersebut.

3. Menganalisis bentuk-bentuk gejala sosial yang terdapat dalam tiga cerpen tersebut.

4. Menentukan posisi individu dalam proses gejala sosial tersebut.

\section{HASIL DAN PEMBAHASAN}

Tiga cerpen Kalimantan Timur tahun 1980-an yang diterbitkan di harian Manuntung menunjukkan gejala sosial dalam ber- bagai bentuk. Relasi antarindividu dalam sebuah lingkungan baru menampilkan beragam konflik, empati, dan solidaritas.

\section{Cerpen "Kembali ke Desa" karya Mazhar Hanafie (25 Juli 1988)}

\section{Identifikasi Cerpen "Kembali ke Desa"}

Cerpen "Kembali ke Desa" menampilkan percintaan antara tokoh $\mathrm{Aku}$ dan Sunarti. Tokoh Sunarti ditampilkan sebagai kekasih tokoh Aku. Tokoh Aku dan Sunarti sama-sama berada di ruang kota.

Sunarti digambarkan sebagai perempuan yang ingin memajukan desanya. Ia berwatak tegas dan bijaksana. Untuk mewujudkan mimpinya tersebut, ia menuntut ilmu ke kota. Dialog antara Aku dan Sunarti menunjukkan bahwa Sunarti menginginkan desanya mempunyai saluran air yang memadai bagi keperluan masyarakat. Sunarti ditampilkan sebagai perempuan yang tegas dan pantang menyerah.

Sunarti pernah bermimpi tentang desanya yang terendam banjir dan rumah-rumah hanya terbawa arus banjir. Karena mimpi tersebut, cita-cita Sunarti semakin kuat. Ia ingin desanya maju.

\begin{abstract}
Kemauannya yang keras pantang menyerah dalam memperjuangkan citacita serta sikapnya yang tegas dan tepat dalam mengambil keputusan adalah ciri khas sikap dan sifat pribadinya (Hanafie, 1988:VI).
\end{abstract}

Kutipan tersebut menunjukkan kepribadian tokoh Sunarti yang kuat. Ia tidak kenal menyerah. Cita-cita yang ingin diwujudkan Sunarti adalah membuat pengairan pertanian melalui tadah hujan. Hal itu akan membuat petani tidak akan kekurangan air sepanjang tahun. Kualitas produksi dengan demikian akan meningkat.

Saya yakin seandainya lembah itu kita bendung pasti airnya akan berlimpah. 
Lalu tinggal kita atur saluran airnya maka akan terpenuhilah keperluan air sawah pertanian masyarakat desa kita, yang selama ini masih menggantungkan pada turunan air hujan, yang disebut tadah hujan. Dengan demikian petani kita dapat bercocok tanam sepanjang tahun untuk meningkatkan tingkat hidup dan peghidupan masyarakat desa kita. Kemudian kalau produksi sudah meningkat, kita akan segera perbaiki sarana sarana perhubungan dan pemasarannya (Hanafie, 1998:VI).

Untuk mewujudkan cita-cita tersebut diperlukan tenaga-tenaga yang berkualitas di desanya. Sunarti dan tokoh Aku berencana kembali ke desanya untuk membangun tempat kelahirannya rersebut. Kutipan tersebut menunjukkan cita-cita Sunarti bagi desanya. Tokoh Aku mendukung cita-cita Sunarti. Desa tempat tinggalnya memang perlu mendapatkan kualitas sumber daya manusia yang hebat.

... Dan di sinilah aku melihat pentingnya tenaga terdidik dan pemikir di desa. Kalau begitu aku salut dan setuju sekali atas rencanamu untuk kembali ke desa nanti seusai sekolahmu, desa kita memang telah menanti uluran tanganmu (Hanafie, 1998:VI).

Kutipan tersebut menunjukkan dukungan tokoh Aku bagi Sunarti. Tokoh aku berharap Sunarti dapat segera lulus dan dengan latar belakang pendidikannya, Sunarti dapat membawa desanya menjadi desa yang maju.

Namun, cita-cita tersebut hilang karena Sunarti meninggal dunia akibat kecelakaan. Dukungan tokoh Aku terhadap Sunarti tetap sama. Ia kemudian kembali ke desa meneruskan cita-cita Sunarti.

Kini Sunarti telah tiada ...cita-citanya yang luhur tetap ada dan telah bersemayam. Hatiku tergerak oleh .... Tekad bulat di hatiku untuk meneruskan amanahnya.... Dengan semangat ....
Tekad membaja, dilandasi .... Tekad untuk mengabdi, kujinjing kopor tuaku kembali ke desa (Hanafie, 1998:VI).

Kutipan tersebut menunjukkan tokoh Aku tetap mendukung Sunarti meskipun sudah meninggal dunia. Ia kembali ke desa untuk mewujudkan cita-cita.

\section{Gejala Sosial Cerpen "Kembali ke Desa"}

Cerpen "Kembali ke Desa" menunjukkan gejala sosial berupa pertahanan eksistesi tokoh. Tokoh Aku dan tokoh Sunarti ditampilkan berada pada sebuah desa yang belum maju. Pertahanan eksistensi ditunjukkan sebagai individu yang melakukan pertahanan eksistensi dengan menuntut ilmu di kota.

Di lembah gunung pada sebuah desa yangnyaris terpencil itulah kami berdua dilahirkan dalam kondisi lingkungan yang serba terbatas. Serba keterbatasan inilah rupaya mendorong tekad Sunarti untuk menuntut ilmu lebih tinggi ke kota untuk modal dalam membangun desa menjadi desa yang maju, tentram, dan aman.... (Hanafie, 1988:VI)

Kutipan tersebut menunjukkan individu yang melakukan pertahanan eksistensi diri dengan meninggalkan akarnya. Ia merantau untuk mencari ilmu dan digunakan demi kemajuan tempat tinggalnya.

Pertahanan eksistensi diri sangat kuat ditunjuukkan oleh tokoh Sunarti. Sunarti ditampilkan sebagai perempuan yang sangat kuat untuk mengubah desanya menjadi desa yang maju. Keterbatasan di desanya tidak menjadikan ia merasa rendah diri, tetapi menjadikannya kuat.

Saya yakin seandainya lembah itu kita bendung pasti airnya akan berlimpah. Lalu tinggal kita atur saluran airnya maka kan terpenuhilah keperluan air sawah pertanian masyarakat desa kita, yang selama ini masih menggantungkan pada turunan air hujan, yang disebut 
tadah hujan. Dengan demikian petani kita dapat bercocok tanam sepanjang tahun untuk meningkatkan tingkat hidup dan penghidupan masyarakat desa kita. Kemudian kalau produksi sudah meningkat, kita akan segera perbaiki sarana perhubungan dan pemasarannya (Hanafie, 1988:VI).

Kutipan tersebut menunjukkan individu melakukan upaya untuk memajukan lingkungan di sekitarnya. Individu ditampilkan sebagai pribadi yang kuat untuk megubah lingkungan tempat tinggalnya menjadi lebih baik. Individu dengan demikian juga digambarkan sebagai individu yang selalu ingat dengan akarnya. Kepergiannya ke kota bukan untuk meninggalkan desa tempat tinggalnya. Akan tetapi, ia ke kota untuk suatu saat kembali ke desanya. Ruang kota menjadi tempat individu mendapatkan pendidikan.

Tokoh Aku juga ditampilkan sebagai individu yang sadar dengan keterbatasan desanya. Ketika Sunarti meninggal karena kecelakaan, tokoh Aku lalu segera pergi ke desanya.

.... Dengan semangat dan tekad membaja, dilandasi tekad untuk mengabdi, kujinjing kopor untuk kembali ke desanya (Hanafie, 1988:VI)

Kutipan tersebut menunjukkan upaya individu untuk segera kembali ke akarnya demi kemajuan di desanya. Upaya itu untuk menjaga cita-cita individu lain yang telah tiada. Akar sebagai tujuan akhir stelah lama bertempat tinggal di ruang kota.

\section{Cerpen "Keping Hati Menguak Badai" karya Ni Nipah (1 November 1988) Identifikasi Cerpen "Keping Hati Menguak Badai"}

Cerpen tersebut menampilkan seorang guru perempuan yang bertugas di sebuah sekolah di kampung. Guru tersebut berna- ma Riska. Sebagai guru baru, tokoh Riska mendapat tantantangan di sekolahnya sendiri.

Tema sosial ditampilkan melalui kehidupan guru di sekolah di sebuah kampung. Tokoh Riska merupakan seorang wali kelas. Usahanya untuk menjadi guru yang baik dibuktikan dengan prestasinya menjadi guru teladan tingkat kecamatan.

\section{Berkat prestasi dan dedikasinya Riska terpilih sebagai guru teladan tingkat kecamatan. Dan salah satu hadiah ialah jam tangan yang kini melingkar di tangannya (Nipah, 1988:VI).}

Kutipan tersebut menunjukkan kemampuan dan dedikasi Bu Riska sebagai guru telah terbukti. Ia mampu melewati banyak tantangan sehingga layak mendapatkan predikat sebagai guru teladan.

Tekadnya bulat untuk menjadi guru yang menilai murid sesuai dengan kemampuannya. Meskipun ditentang oleh kepala sekolah, tokoh Riska tetap tidak menaikkan salah satu muridnya yang bernama Lowa. Lowa adalah anak seseorang yang mewakafkan tanah bagi sekolah tersebut. Kepala sekolah tidak mau Riska dan sekolahnya mempunyai masalah dengan Pak Linta

“Bu, Bu Riska! Ibu tahu kan, Lowa itu anak siapa!!!" kata Pak Johan setengah berteriak.

"Saya tahu, Pak," dengan suara yang dibuat ketus. Riska melanjutkan....

"Maaf, Pak, sebagai wali kelas tentu lebih tahu kemampuan anak didik saya. Apa jadinya kalau Lowa dipaksakan naik sedangkan kemampuannya belum memadai." (Nipah, 1989:VI).

Kutipan tersebut menunjukkan tokoh Riska mantap dengan keputusannya. Ia tidak mengambil keputusan yang salah. 
Orang tua Lowa, Pak Linta, marah karena Riska tidak menaikkan anaknya.

"Guru baru kemarin sore, sudah mulai berlagak, apa salah anak saya. Hingga tidak naik kelas. Kalau belum becus menjadi guru, nggak usah mengajar di sini," sambil tangannya yang kokoh menunjuk muka Riska....

"Ka... karena anak bapak jarang sekolah dan dia sering membuat keributan," dengan suara terbata-bata Riska memberi pengertian pada Pak Linta.

Pak Linta semakin marah (Nipah, 1988:VI).

Kutipan tersebut menunjukkan harapan orang tua yang terlalu besar terhadap anaknya. Kegagalan yang diterima anaknya tidak dapat diterima oleh orang tua. Orang tua itu bahkan memarahi guru anaknya.

Keputusan yang diambil Riska membuat Pak Linta sangat marah. Kemarahan itu reda ketika kakaknya datang menceritakan pengalaman anaknya yang tidak dapat melanjutkan SMP di kota.

"Kau masih beruntung Linta, berarti kau masih ada kesempatan untuk mengarahkan anakmu agar belajar lebih giat dan lebih rajin. Jangan seperti aku, apa artinya kekayaan yang kukumpulkan bertahun-tahun kalau Sanu, anak$\mathrm{ku}$, tidak bisa melanjutkan SMP ke kota. Akulah yang salah selama ini. Aku telah memaksakan kehendakku sendiri agar Sanu bisa dinaikkan dan akhirnya lulus, walau sebenarnya otak serta kemampuannya belum memadai." (Nipah, 1988:VI)

Kutipan tersebut menunjukkan orang tua yang akhirnya sadar tentang kemampuan anaknya. Pemaksaan menaikkan kelas anak tidak akan bermanfaat bagi si anak itu sendiri. Pak Linta dan Riska akhirnya saling memafkan.

\section{Gejala Sosial Budaya Cerpen "Keping Hati Menguak Badai"}

Pada cerpen "Keping Hati Menguak Badai" terdapat gejala sosial budaya berupa pertahanan eksistensi manusia di luar daerahnya. Tokoh Riska ditampilkan menjadi guru di luar daerahnya. Ia ditampilkan sebagai individu yang kokoh dengan pendirian.

Konflik antartokoh terjadi ketika tokoh Riska diminta menaikkan muridnya yang bernama Lowa. Keputusannya untuk tidak menaikknya Lowa, salah satu anak orang yang paling berjasa bagi sekolah, tidak dapat diubah lagi.

“Bu, Bu Riska! Ibu tahu kan, Lowa itu anak siapa!!!” kata Pak Johan setengah berteriak.

"Saya tahu, Pak," dengan suara yang dibuat ketus. Riska melanjutkan....

"Maaf, Pak, sebagai wali kelas tentu lebih tahu kemampuan anak didik saya. Apa jadinya kalau Lowa dipaksakan naik sedangkan kemampuannya belum memadai." (Nipah, 1988:VI).

Kutipan tersebut menunjukkan konfik antarindividu. Keputusan tokoh Riska menunjukkan pertahan eksistensi individu di tengah-tengah usaha individu lain untuk mengubah keputusannya. Individu memberikan argumentasi tentang keputusannya tidak menaikkan salah seorang muridnya.

Pertahanan eksistensi juga tampak pada saat tokoh Riska menjawab Pak Linta, orang tua, Lowa.

"Guru baru kemarin sore, sudah mulai berlagak, apa salah anak saya. Hingga tidak naik kelas. Kalau belum becus menjadi guru, nggak usah mengajar di sini," sambil tangannya yang kokoh menunjuk muka Riska....

"Ka... karena anak bapak jarang sekolah dan dia sering membuat keributan," dengan suara terbata-bata Riska memberi pengertian pad Pak LInta. 
Pak Linta semakin marah (Nipah, 1988:VI).

Kutipan tersebut menunjukkan pertahanan eksistensi seorang individu yang berprofesi sebagai guru. Konflik antarindividu terjadi antara guru dan orang tua. Individu yang memberikan harapan besar pada anaknya melakukan upaya intimidasi kepada pihak lain. Individu melakukan pertahanan diri dengan memberikan penjelasan mengenai kondisi dan kemampuan anaknya di sekolah.

Pertahanan eksistensi diri tersebut berhasil karena invidu lain menyadari kesalahnnya. Individu akhirnya tetap menjalankan profesinya di tempat semula. Pada awalnya individu berencana meninggalkan kampung tersebut. Akan tetapi, individu akhirnya bersedia tetap mengajar di sekolah itu karena masyarakat menginginkannya.

“Terima kasih atas perhatian Bapak pada saya. Bila Tuhan mengijinkan dan pemerintah serta masyarakat masih menghendaki saya mengajar di sini. Saya tetap akan di sini. Saya sangat mencintai kampung ini, Pak." ... (Nipah, 1988:VI).

Cerpen "Keping Hati Menguak Badai" menampilkan individu yang melakukan pertahanan eksistensinya di lingkungan baru. Pertahanan terhadap pendirian menimbulkan berbagai konflik terjadi. Konflik yang terjadi antarindividu di dalam internal tempatnya bekerja dan konflik eksternal dengan individu di luar tempatnya bekerja.

\section{Cerpen "Surat dari Kekasih" karya Said Ags. S. (5 Januari 1989)}

\section{Identifikasi Cerpen "Surat dari Kekasih"}

Cerpen "Surat dari Kekasih" menampilkan persahabatan antara tokoh Aldi dan Prasetyo yang bekerja di negara Brunai. Satu sama lain saling berbagi persoalan masing-masing.
Aldi dan Prasetyo yang bekerja di negara lain masing-masing mempunyai kekasih yang berada di Indonesia. Surat yang dikirimkan kepada mereka merupakan harapan tentang kabar baik. Akan tetapi, surat dari kekasihnya mengabarkan sesuatu hal yang buruk.

"Hei, tunggu dulu! Sebelum kau membaca surat dari do'i mu kau harus mendengarkan dulu surat yang kudapat Saraswati...."

Akhirnya dia rela menikah dengan pilihan orang tuanya. Aku harus bagaimana Al?" keluhnya dengan wajah semakin sembab dengan air mata

“... Tiga tahun kubangun pilar cinta$\mathrm{ku}$ dengannya, dengan harapan kelak kalau aku kembali ke tanah air, aku bisa mewujudkan angan-anganku. Tapi... ah ternyata kawin adat, perjodohan, dan orang tuamu masih tetap tak bisa meninggalkan kebiasaan lama." (Said Ags. S, 1989:VI).

Kutipan tersebut menunjukkan Aldi dan Prasetyo sama-sama telah diputuskan oleh kekasihnya. Persahabatan di antara keduanya ditunjukkan dengan saling menguatkan satu sama lain pada saat persoalan percintaan terjadi.

“... Begitu juga aku, kita seperti saudara, Pras, jadi kumohon kau menerima kenyataan ini dengan pikiran lapang. Mungkin Saraswati memang bukan jodohmu," nasihatku lagi panjang lebar.

"Kuharap kau bisa tetap tegar, Al. Bukankah kau yang menyuruhku agar dapat menerima kenyataan? Kini kita benar-benar senasib. Saraswati memutuskan cintaku dan Ratih memupuskan harapanmu," ucap Prasetyo lagi (Said Ags. S., 1989:VI).

Kutipan tersebut menunjukkan Aldi dan Prasetyo saling menguatkan. Mereka ditampilkan mempunyai keadaan yang sama. Aldi dan Prasetyo saling menguatkan dalam keadaan tersebut. 
Gejala Sosial Cerpen "Surat dari Kekasih"

Cerpen tersebut menampilan gejala sosial budaya berupa pertahanan eksistensi diri manusia. Tokoh Aldi dan Prasetyo ditampilkan sebagai individu yang mempertahankan eksistensi dengan merantau ke luar negara untuk bekerja.

Seperti rajinnya anak muda yang jauh dari kampung halaman, maka pahit getir dan suka duka hidup di negeri orang lain cukuplah membuat aku kadang hampir menangis....

Aku telah memasuki tahun ketiga bekerja di negeri yang sebenarnya banyak mempunyai persamaan dengan negeri kita tercinta Indonesia (Said Ags. S., 1989:VI).

Kutipan tersebut menunjukkan manusia yang melakukan pertahanan eksistensi ke negara lain untuk meningkatkan status ekonomi. Persoalan manusia yang hidup di luar akarnya merupakan tantangan tersendiri bagi individu.

Pertahanan eksistensi ditunjukkan pada saat Aldi dan Prasetyo mengalami nasib yang sama, yaitu diputuskan kekasihnya masing-masing. Mereka melakukan pertahanan eksistensi dengan saling memberi semangat satu sama lain.

\begin{abstract}
“... Begitu juga aku, kita seperti saudara, Pras, jadi kumohon kau menerima kenyataan ini dengan pikiran lapang. Mungkin Saraswati memang bukan jodohmu," nasihatku lagi panjang lebar.

"Kuharap kau bisa tetap tegar, Al. Bukankah kau yang menyruhku agar dapat menerima kenyataan? Kini kita benar-benar senasib. Saraswati memutuskan cintaku dan Ratih memeupuskan harapanmu," ucap Prasetyo lagi (Said Ags. S., 1989:VI).
\end{abstract}

Kutipan tersebut menunjukkan individu melakukan pertahanan eksistensi pada saat mengalami persoalan yang berat.
Semangat dari individu lain adalah salah satu cara untuk mengubah keadaan menjadi membaik. Persoalan tersebut menjadi tanggung jawab bersama.

\section{PENUTUP}

Hasil analisis tiga cerpen Kalimantan Timur tahun 1980-an menunjukkan berbagai gejala sosial yang terdapat dalam cerpen-cerpen tersebut. Bentuk gejala sosial berupa migrasi merupakan salah satu pilihan manusia untuk memperoleh kondisi yang lebih baik secara sosial ekonomi. Manusia yang sama-sama bermigrasi ditampilkan mempunyai bentuk relasi sosial yang kuat. Peduli dan tenggang rasa ditunjukkan dalam relasi sosial antarperantau yang ditampilkan dalam cerpen-cerpen tersebut.

Dengan adanya bentuk pertahanan eksistensi di daerah migrasi, kembali ke akar menjadi sebuah fenomena. Dalam cerpen tersebut juga ditunjukkan bahwa kembali ke akar dan mengabdikan diri ke akar merupakan bentuk pengabdian bagi manusia yang telah bermigrasi.

Dalam cerpen-cerpen tersebut, proses manusia beradaptasi di daerah migrasi terjadi berbagai konflik, baik konflik antarindividu maupun konflik dengan diri sendiri. Nilai-nilai sosial seperti empati, solidaritas, dan komunikasi yang baik masyarakat dengan invidu menyelesaikan konflik tersebut. Tiga cerpen Kalimantan Timur menampilkan pertahanan eksistensi manusia di luar daerahnya.

\section{DAFTAR PUSTAKA}

Endraswara, Suwardi. 2002. Metodologi Penelitian Sastra. Jakarta: CAPS.

Escarpit, Robert. 2008. Sosiologi Sastra. Jakarta: Yayasan Obor Indonesia.

Hanafie, Mazhar. 1988. "Kembali ke Desa". Harian Manuntung, 25 Juli 1988.

Koentjaraningrat. 2015. Pengantar Antropologi Sastra. Jakarta: Rineka Cipta. 
Kuntowijoyo. 2006. Budaya dan Masyarakat. Yogyakarta: Tiara Wacana.

Moleong, Lexy J. 1994. Metodologi Penelitian Kualitatif. (T. Surjaman, Ed.) (5th ed.). Bandung: Remaja Rosdakarya.

Nipah, Ni. 1988. "Keping Hati Menguak Badai", Harian Manuntung, 1 November 1988.

Prijanto, Saksono, dkk. 2007. Novel Peranakan Tionghoa Tahun 1930-an: Tinjauan Sosiologis. Pusat Bahasa: Jakarta.
Said Ags.S. 1989. "Surat dari Kekasih". Harian Manuntung, 5 Januari 1989.

Soekanto, Soerjono dan Budi Sulistyowati. 2019. Sosiologi Suatu Pengantar. Depok: Rajawali Press.

Teeuw A. 2003. Sastera dan Ilmu Sastera. Bandung: Dunia Pustaka Jaya.

Wellek, Rene dan Austin Warren. 1993. Teori Kesusastraan. Jakarta: Gramedia Pustaka Utama. 